\title{
FATHOM
}

\section{Narrative silences in Far from the Madding Crowd}

Les silences narratifs dans Far from the Madding Crowd

\section{Michel Morel}

\section{OpenEdition}

\section{Journals}

Electronic version

URL: http://journals.openedition.org/fathom/373

DOI: $10.4000 /$ fathom.373

ISSN: 2270-6798

\section{Publisher}

Association française sur les études sur Thomas Hardy

\section{Electronic reference}

Michel Morel, "Narrative silences in Far from the Madding Crowd», FATHOM [Online], 2 | 2013, Online since 23 July 2013, connection on 01 May 2019. URL : http://journals.openedition.org/fathom/373 ; DOI : $10.4000 /$ fathom.373

This text was automatically generated on 1 May 2019. 


\title{
Narrative silences in Far from the Madding Crowd
}

\author{
Les silences narratifs dans Far from the Madding Crowd
}

\author{
Michel Morel
}

\section{EDITOR'S NOTE}

This article was first published in Cycnos 26.2, "Thomas Hardy: Far from the Madding Crowd / Loin de la foule déchainée" special number (Paris: L'Harmattan, December 2010): 13-28, and subsequently in the e-journal Revel: http://revel.unice.fr/cycnos/index.html?id=6368. It is reproduced here by special authorization from cycnos.

1 "Silence has sometimes a remarkable power of showing itself as the disembodied soul of feeling wandering without its carcase, and it is then more impressive than speech. In the same way, to say a little is often to tell more than to say a great deal" (Hardy 1986, 100). I would like to investigate this means that "says much" (115) and is "more effective than words" (156), in its typographical inscriptions, resorting as a method to what could be called affective stylistics.

2 I am here interested in paratextual elements, more specifically in the three series of typographical silence-markers (see Doc. 1 in the annexes) - first, "2-m rules" or " $2-\mathrm{m}$ dashes"; second, "ellipsis" symbolized by the (Victorian) spaced dots; third, "m rules" or " $m$ dashes" (a few examples of which are collected in Doc. $2^{1}$ ). These literally proliferating typographical signs are hardly noticed, and possibly absented by the reader on first reading the text. And yet, they keep puncturing the narrative under the pressure of emotions and desires, and of what cannot be said, either because there is no word for it or it is improper in relation to the prevailing values of the day. 


\section{Three typographical markers of silence}

\section{A) 2-m rules (in French: 'doubles cadratins')}

3 This is the most striking and effective narrative aid - fifty-seven occurrences - given to the reader in Far from the Madding Crowd. Leaving aside the more classical use of the 2-m rule such as in the examples listed in Doc. 2 under A.1. conventional and A.2. interruption, let us tackle the most telling case (the second example under A.3. aposiopesis), Gabriel's ponderings during the storm. A similar analysis could be carried out for several of the examples collected in Doc. 2.

4 To explain: an "aposiopesis" is a sudden suspension of speech for whatever reasons, and there are many, when a feeling gets the better of the speaker (Dupriez 64-65). In the example of Gabriel's inner musings, the text reads: "Oak suddenly remembered that eight months before this time he had been fighting against fire in the same spot as desperately as he was fighting against water now-and for the futile love of the same woman. As for her--But Oak was generous and true, and dismissed his reflections." (Hardy 1986, 197)

5 A whole multi-stage axiological drama is played out for us in the suspended "As for her --". The rhetorical figure first embodies the eloquent curtailing of speech under the shock of a pre-conscious affect, then causing a spurt of emotion (here loss and dereliction). Gabriel's devotion to a woman we know does not care for him - a typical example of dramatic irony - is clearly mapped. As a result we identify with the hopeless hero and accept his apparently implied version of the relations between men and women. His immediate reaction seems to be contaminated by a consensual view on the traitorousness of the other sex, accompanied with self-aggrandizement, selfdramatization and self-pity (not to speak of a latent masochistic dimension); something of the emotional blackmail familiar to those who sacrifice themselves to others. This discreditable response, a sort of psychological archetype, is promptly framed and contradicted by the narrator in the immediate second moment, a crucial narrative intervention: Gabriel cannot think that because he is "generous" and "true", a remark which contrastively positions the high moral status of Gabriel, but is literally ideological, referring us as it does to the values of the time under cover of a general pronouncement. The result is that we tend to endorse the right and wrong of the situation according to the text. Moreover, this temporary silence is powerfully proleptic since it implicitly proffers a tacit promise, in unspoken equivalence to its very denial, about a happier relationship between the two 'lovers' in a wishful future.

6 A remark concerning the nature of suspense, in itself and in general, might be apposite here. In this particular example, the reader is naturally made anxious (if only for a second) about the outcome of the mini-crisis enacted in this aposiopesis. In reality, the crucial point only superficially concerns what will happen or not. What is at stake is the foundational values tested in this passing emergency. In the surge of suspense they seem to be threatened and even jeopardized. The reader, who has progressively come to share such values, agonizes about the ordeal they undergo: here, the temporary doubt about Gabriel's generosity and truth, whatever these may mean. He or she hence validates the inferred criterion without even thinking about the operation. Which shows that in this case as ever, suspense is intensely axiological in its workings and consequences. The yet undecided crux in it, becomes a key component in the reading compact with the text (the 
story itself, the values in the balance, our own beliefs). To which must be added the dangerously generalizing dimension of romance: "Un homme et une femme", the eternal, unchanging love story which is so pleasant to play with; perhaps the central spring in this novel, even when it risks veering into its contrary, tragedy.

The momentary hesitation in Gabriel's attitude marked out by the 2-m rule is the site of a triple judgment passed by the narrator in reference first to himself as our moral guide, second to the protagonist's rectitude, and third to our supposed understanding (with our answering triple response judgments). We therefore instantly, but unconsciously, readjust and sharpen our private moral intercourse with the text, and so are we made to progress from adjustment to adjustment, until the end of the novel. This ephemeral silence here foregrounded under the form of an aposiopesis is consequently doubly charged, first in the direction of the narrative system at work, and second in that of the author's practices in this domain. Of this more hereafter.

\section{B) Ellipsis (not to be mistaken for elision)}

8 One might first be led to think that 2-m rules and suspension dots - twenty-nine occurrences in the novel - are equivalent. This should be looked into. Beyond its ordinary conventional roles, as the marker of suggestion, ellipsis often plays the part of a kind of stage direction helping us to assess the attitude of the character (the actorial dimension) and the attendant judgment passed on it (the auctorial dimension ${ }^{2}$ ), the two often coming in successive phases making us pass from a descriptive stage to an assessment of the attitude described. This is clearly the case in the second example in B.2. actorial and auctorial: "Unfeeling thing that you are. ... But I'll see if you [...] dare do such a thing"' (Hardy 1986, 154). Bathsheba's wilful self-ignorance and compensatory excess of authority (at the expense of poor Liddy), are both immediately distanced - the auctorial dimension -, into a kind of smile. This ellipsis and the silence it lays bare are fraught with the judgments we are made to pass on both Bathsheba and a servant totally dependent on her mistress, with the latent, but important fall-outs concerning Troy as a "fast man" (same page).

9 The type of silence ellipsis betokens is also central in matters of suspense, as is clearly shown in the scene when Bathsheba confronts Fanny's coffin (B.3. plot, second example): "'Would to God you would speak and tell your secret, Fanny! ... O, I hope, I hope it is not true that there are two of you! ... If I could only look in upon you for one little minute" (227). The two consecutive suspensions of the voice are eloquent, but their meaning is rather difficult to pinpoint with certainty. They are graphic representations of the scene, but what really counts is the implicit appraisal that goes along with them: Bathsheba's curiosity suggests a certain immature narrow-mindedness; she thinks of herself, not of Fanny. The young woman's self-delusions, her yearning for the physical proofs of her husband's adulterous relation with Fanny ("your secret") are unambiguously displayed. Moreover, one is nearly made to think that the situation might not be so bad if there was no baby. To this must be added the context pertaining to such a scene, the contemporary attitude to the "wife" confronted with the (dead) "mistress", and the Victorian obsession about the fallen Magdalen (as in Wilkie Collins's novels). A quasi necrophiliac desire is also evidenced in this climactic encounter, reminding us of very similar situations in chapters XVI and XXIX of Wuthering Heights, and the repressed but very active voyeurism attendant to them: we too wish the coffin to be opened. The scandalized worries of the 
protagonist make us side with her in her violent reaction to Troy's semi-sincere romantic pose at the end of the chapter. Both cases of ellipsis are therefore crowded with repressed affects, in matters of death in particular, which literally energize this moment in the story, making it verge on melodrama. Hence a series of rather primitive deductions on our part, at least when reading the text for the first time, since we cannot help being engrossed by this out-of-the-ordinary dimension, and feel more than think, all of this being continued and confirmed later in the chapter, by means of dramatic irony, when we gloat on Troy's discovery of the situation.

The moral line is more blatant in the unique example in the novel of an aposiopesis in the form of ellipsis (B.4. aposiopesis): the silence it encrypts seems dangerously to play up to the conceptions of the contemporary public: "[...] he suddenly said [...] that his constancy could not be counted upon unless I became his.... And I was grieved and troubled--' (196): his "wife", or his "mistress"? The second alternative does not fit the cumulative evidence about Bathsheba who may be a flirt but would never transgress the rules of womanly virtue according to the period. And yet such a possibility is somehow adumbrated and makes us shiver at the mere thought of what her wrong-headedness has caused her to risk. In other words we unknowingly accept the whole moral system, as we do earlier on (B.3 Plot., first example) when Bathsheba vents her fears about Fanny's fate: "'I do hope she has come to no harm through a man of that kind...." (58). In comparison, the silence indicated by the double 2-m rule above: "And I was grieved and troubled--" suggests something quite different. It is heavily weighed with the imbalanced interaction between the two characters: Bathsheba seems paradoxically to call for Gabriel's moral support while she is actually wounding him, but also to want to be excused for her preceding suggestion and perversely to try to attenuate its effect on the clearly dumbfounded Gabriel. A perfect double-bind for him that leaves him tongue-tied, his muteness being partly caused by the social difference that separates him from her. We are thus led to share his quandary, the clipped sentence following the paragraph by way of conclusion, tersely rounding off the moment: "Gabriel made no reply". Not to forget that the apparent annihilation of our romantic expectations about the two estranged protagonists, adds a proleptic dimension which is all the stronger for being provisionally denied.

\section{C) $m$ rules (in French: 'cadratins')}

$11 \mathrm{M}$ rules abound in the text and their use is obviously more varied. Three facets can be traced here, beyond the conventional indication of interpolation, or the marking of the first cue in a dialogue (C.1. conventional).

12 To start with the most explicit use, the mimetic interruption in the flow of the voice, first Fanny's and then Bathsheba's, evidences the pressure of irrepressible emotion (first and last cases in C.2. mimetic): “'And you said lots of times you would marry me, and-and-II-I-_"' (72), Fanny's sobs finally overcoming her. Bathsheba's spasmodic expostulation at the spectacle of Troy kissing Fanny's corpse is more complex: “If she's-that,-whatam I?"' (231): the successive pauses betray her gradual inner realization of the actual situation. In both cases though, we are given the rather objectionable pleasure of witnessing, condoning and supposedly understanding all about woman as the weaker vessel in the grip of a seducer. Such scenes obviously come to weigh heavily on the final judgment passed on Troy. One might say that they exemplify narrative persuasion at 
work. A naive or empathic reader, reacting to these passages in conformity to what is charted for him or her, would be very much like a child biting his fingers in an agony of anticipation.

13 An interesting case is illustrated by the initial $\mathrm{m}$ rule in the fourth example of C.2. mimetic : 'O no-I don't think that' / '-But the truth of the matter is that there was not, as some fancy, any jilting on-her part' (199). Boldwood's honest desire to put matters right makes us side with his awkward sincerity (especially as he is talking to Gabriel). The slight hesitation illuminates the complexities of a natural man and his tortured genuineness. A judgment is temporarily passed on him here which places him on the positive side (and Bathsheba conversely, on the negative one, in inverted proportion).

The remarkably effective description of Troy's death touches on the complementary dimension of a sort of silence deliberately left to speak for itself (last example in C.3. Plot): "He uttered a long guttural sigh-there was a contraction-an extension-then his muscles relaxed, and he lay still" (290). The syntactic pause is stressed four times in succession, since the final comma interrupts the sentence too, but at a level closer to the narrator's own voice. The halting progression vividly but laconically depicts the mechanical movements of a dying body, in a remarkably restrained and self-mastered rendition. We can as it were "hear" the narrator's own silence, which is a commentary in itself; something like a primitive: "serves him right". Troy has finally failed the ordeal of truth, the truth the story stands for. He takes his place in the anticipated axiological hierarchy established at the end of this or any novel. In such a rendering, the m rule can be said to achieve a maximum effectiveness in the guidance of the reader.

$\mathrm{M}$ rules are sometimes used to indicate a temporary suspension, but a less marked and more ambiguous one than in the case of 2-m rules. A slightly perplexing case is provided by Gabriel's answer to Boldwood in their final dialogue (last example in C.4. aposiopesis): 'Her meaning may be good; but there-she's young yet' (277). One should first recollect that the whole passage coming under sub-chapter III (275-277) is fundamentally ambivalent since Gabriel has to assuage Boldwood's qualms concerning Bathsheba, while at the same time secretly experiencing the tragic certainty that if Boldwood were to succeed, his own hopes would come to an end. His answer is consequently laden with his own silence, a typical example of dramatic irony since we are implicitly given the means to understand what totally escapes Boldwood. A structuring dimension of the story is implicitly made to surface here: whenever the conversation touches on Bathsheba, Gabriel is forced into a reserved, repressed, shackled attitude since he cannot express a feeling which is literally illegitimate and unauthorized. He is accordingly condemned to a kind of docility that contrasts with what we know of his strength and manliness, and makes such inner tension ever more tragically convincing. This seems to be the case in this harmless "there-" whose exact meaning is quite difficult to ascertain. Gabriel is obviously wary of provoking any outburst on the part of a man in the grip of a passion bordering on frenzy. Yet what he actually means is not plain at all. Does this "there-" correspond to a self-imposed interruption and the censoring of something he cannot say; does it indirectly point to Bathsheba's latest promise as a recurring example of what she does to men? His suspended sentence might then be taken to reflect his personal doubts, a tempting interpretation. As in so many other cases, this $m$ rule lays bare the complex explicit and implicit exchanges between characters (three, in this case). At the same time, its proleptic dimension cannot be denied, since it revives in us the thwarted hope of a happy conclusion. Indeed, at this stage in the story, Gabriel has progressively come to 
embody resilience, a capacity for self-mastery and concealed dignity that strongly furthers the expectations of a reader who more and more eagerly desires the hero's happiness.

\section{Meanings}

16 A rapid verification shows that in Jude the Obscure Hardy still uses ellipsis and m-rules (much less than in Far from the Madding Crowd), but only once resorts to the 2-m rule, for "the w-- of Babylon" (VI, 7, 461); possibly because the author now rejects means befitting a serialized novel published under pressure. This being said, to distance oneself from the powerful effects of such typographical interruptions demands a pointed critical effort. Our spontaneous tendency is to allow them to work on us subliminally. We understand their fleeting message, we enact and "concretise" them, as Wolfgang Iser shows, that is we fill in the gaps they program for us with what Umberto Eco calls our encyclopaedia (all of our acquired experience at the time of our reading), our quick response leaving us unaware of the whole transaction. The transience of this exchange might be compared to that of the ephemeral imprint on our retina of the separate images composing a film. And yet such signs strongly guide us, while making us reminisce and anticipate at the same time. Whether one can resist their tacit but potent influence without destroying the pleasure of living with and through the text is a moot question. The fact remains that they are the textual sites where we most desire to be at one with the story, because the silence they materialize is fraught with revulsions and yearnings, misapprehensions and enlightenments. They are a major generic source of identification. They may possibly not remain absolutely effective for us today, but they apparently were so for Hardy's common readers. As shown in the first example - other similar cases could have been taken -, they tend to articulate the general consensus. A later novelist, who regarded Hardy as a kind of predecessor, was to reproach him with this latent conformism: D. H. Lawrence accused him of finally bowing to contemporary beliefs by first making his protagonists breach the collective moral wall, and then cutting off their heads.

The only moment of global distance in the story comes at the very end when Coggan and Joseph both mock the way Oak now calls Bathsheba "his wife", the narrator adding that Bathsheba "never laughed readily now" (Hardy 1986, 308). We are left with the chorus's critical remarks climaxing in Joseph's negative biblical taunt about Gabriel having joined the "idols" of matrimony; Hosea's next vituperation against Israel, in the same biblical passage, being: "they have committed whoredom continually" (Hosea 4.18). When Joseph adds: "But since 'tis as 'tis, it might have been worse" (308), we tend to feel that the country folks' glumness in matters of love is given the last word, an apparent return to a pessimistic sense of reality undercutting romance and the dreams of ingenuous readers. We have been given to understand that Joseph is not the most balanced character in the group, yet his pronouncement might be an opportunity for us to gauge, and reflect on, the devices repeatedly used, up to the very end of the novel, to gain our positive participation in its make-believe.

I personally have long been convinced that if Hardy finally gave up writing novels, after the odious reception given to Jude the Obscure in 1896, it was because the double generic pressure - the archetypal in the telling of any story and tragedy -, were inimical to his radical socio-cultural aims; for instance, his bitter reconstruction of a young man's fate, 
whom society prevents from fulfilling his legitimate desires and from living how he would have liked to. Hardy had possibly realized at last that it was the novelistic machine itself which induced his public to misread him so lamentably.

If the silences encoded in Far from the Madding Crowd by means of the three typographical figures investigated here, all work in an axiological direction which in the end seems to satisfy the mores of the time, an even more problematic aspect is that these are apparently given general validity, a validity which one might call ethnocentric since the text makes one extrapolate from local and relative truths to a trans-historic dimension. This is perhaps the greatest risk attached to romance and more generally to love stories per se, whether they keep to the 'romantic' as here or plunge into tragedy as in Tess, and centuries before it, in Romeo and Juliet. Romance, the fairy tale for adults, and tragedy, are just the reverse of each other, and both lead to the same cul-de-sac.

20 And yet, the effectiveness in the use of narrative silences in Far from the Madding Crowd is fascinating when considered in terms of verisimilitude and plausibility. Again and again those simple typographical devices foster the elementary gratification of believing and thinking "this is really like life", a pleasure without which one would not read novels at all. The proposed exercise in critical distance thus ends in a rather comic and nostalgic admission of failure. One is finally faced with inextricable contradictions between seduction, enjoyment and a slight revulsion against such brazenly persuasive means. But I am not the first to have fallen a prey to this writer's ways. The many pilgrims roaming, year after year, Hardy-land are a living proof of it. All one can say, is that a commendable critical method should try at least to reach the point where one enjoys the text, but knows exactly the doubtful reasons why; which is what these observations on the textual inscriptions of silence in Far from the Madding Crowd have tried to achieve and advance.

\section{Postscript}

21 The present analysis refers to punctuation in the novel as it stands in the Norton critical edition. The editorial choices in it correspond to those of the Papermac (1969) and Penguin Popular Classics (1994) editions, all three based on the Wessex Edition published by Macmillan in 1912. Those editions include the revisions of later times, unlike the Penguin Classics edition of 2000 published by Rosemarie Morgan (Far from the Madding Crowd, edited with an Introduction and Notes by Rosemarie Morgan with Shannon Russell, Penguin Classics, 2000), which uses the first edition in volume form of Hardy's novel. Given the number of variants in the different editions, any attempt at dealing with punctuation is a very difficult task. R. C. Schweik and M. Piret (314-321) suggest the manuscript version may have been faulty in terms of punctuation: "Hardy's treatment of punctuation of dialogue was so casual and unsystematic that he plainly expected-indeed required-editorial intervention to fill in and complete his accidentals" (315). They quote a passage ("What had become of Boldwood?- [...]", 316), that one can compare with the final version in the Norton text (291), and that clearly shows "inconsistency in the treatment of the accidentals" (316). Concerning the general problem of Hardy's revisions, Schweik and Piret conclude: "the Wessex text has, at least for Far from the Madding Crowd, a stronger claim as a choice for copy-text than may be true for editions of some other of Hardy's novels" (321), which may justify Schweik's statement in the Foreword: "I have attempted to take that process [revisions by Hardy] into account and to provide a critical text that represents in every respect Hardy's final deliberate intention." (Hardy 1986, xi) 
Whatever the case may be-whether or not the "final deliberate" intention should have pride of place over the original one-it is important to note that the typographical choices are basically the same in the Norton and the Penguin editions, with only a few minor differences. A complementary remark may be apposite here: all the incidentals analysed in this paper tend to accentuate silences, hesitations, dramatizations, moments of suspense that point in the direction of a melodramatic tendency not unfaithful to the general intent of the text as we now read it. This critical investigation has been implemented on the basis of such an assumption.

\section{BIBLIOGRAPHY}

Dupriez, Bernard, Gradus - Les procédés littéraires, Paris: Union générale d'édition, 1984.

Eco, Umberto, Lector in fibula (1979), Paris: Grasset, 1985.

Hardy, Thomas, Far from the Madding Crowd (1874), ed. Robert C. Schweik, New York and London: Norton Critical Edition, 1986.

Hardy, Thomas, Jude the Obscure (1895), London: Penguin Classics, 1978.

Iser, Wolfgang, The Act of Reading, A Theory of Aesthetic Response, Baltimore and London: The Johns Hopkins UP, 1978.

Lawrence, D. H., Study of Thomas Hardy and Other Essays, ed. Bruce Steele, Cambridge: Cambridge UP, 1985 .

\section{APPENDIXES}

\section{Document I}

Bathsheba Talks With Her Outrider (Hardy 1986, 273)

'I once seriously injured him in sheer idleness. If I had never played a trick upon him, he would never have wanted to marry me. $O$ if I could only pay some heavy damages in money to him for the harm I did, and so get the sin off my soul that way! . . . Well, there's the debt, which can only be discharged in one way, and I believe I am bound to do it if it honestly lies in my power, without any consideration of my own future at all. When a rake gambles away his expectations, the fact that it is an inconvenient debt doesn't make him the less liable. I've been a rake, and the single point I ask you is, considering that my own scruples, and the fact that in the eye of the law my husband is only missing, will keep any man from marrying me until seven years have passed-am I free to entertain such an idea, even though 'tis a sort of penance-for it will be that? I hate the act of marriage under such circumstances, and the class of women I should seem to belong to by doing it!' 
'It seems to me that all depends upon whe'r you think, as everybody else do, that your husband is dead.'

'I shall get to, I suppose, because I cannot help feeling what would have brought him back long before this time if he had lived.'

'Well, then, in religious sense you will be as free to think o' marrying again as any real widow of one year's standing. But why don't ye ask Mr. Thirdly's advice on how to treat Mr. Boldwood?'

'No. When I want a broad-minded opinion for general enlightenment, distinct from special advice, I never go to a man who deals in the subject professionally. So I like the parson's opinion on law, the lawyer's on doctoring, the doctor's on business, and my business-man's-that is, yours-on morals.'

'And on love-_'

'My own.'

'I'm afraid there's a hitch in that argument,' said Oak, with a grave smile.

She did not reply at once, and then saying, 'Good evening Mr. Oak,' went away.

She had spoken frankly, and neither asked nor expected any reply from Gabriel more satisfactory than that she had obtained. Yet in the centremost parts of her complicated heart there existed at this minute a little pang of disappointment, for a reason she would not allow herself to recognize. Oak had not once wished her free that he might marry her himself-had not once said, 'I could wait for you as well as he.' That was the insect sting. Not that she would have listened to any such hypothesis. O no-for wasn't she saying all the time that such thoughts of the future were improper, and wasn't Gabriel far too poor a man to speak sentiment to her? Yet he might have just hinted about that old love of his, and asked, in a playful off-hand way, if he might speak of it. It would have seemed pretty and sweet, if no more [...]. (emphases added)

A. "And on love-_" $=2-m$ rule or 2-em rules ('double cadratin'); unspaced before and after.

B. "that way! ...."= ellipsis: also, spaced dots ('ellipse ajourée'); dot, dot, dot or ellipsis dots (normal typographical form: flush dots).

C. "passed-am I free to entertain such an idea, even though 'tis a sort of penance-for it will be that?" $m$ dash or $m$ rule ('cadratin'); here unspaced before or after.

D. Other signs to be noted: italics, and contractions suggesting reported speech.

\section{Document II}

\section{A. '2-m rule' / 'double tiret cadratin'= --}

\section{Conventional:}

- 'I believe you saved my life, Miss--I don't know your name.' (missing name - 22)

- 'Farmer Oak-I--' she said, pausing for want of breath [...] (mimetic - 26) 
- '--And so 'a lost himself quite' (diegetic - 49; also 51)

- 'Why, upon my s--' / 'Don't-don't I wont listen to you-you are so profane!' (

blasphemy) - 134; in all, four cases: pp. 31, 134, 202, 284)

\section{Interruption:}

- 'I wasn't thinking of any such thing,' said Gabriel simply; 'but I will-_' 'That you won't.'(bantering - 23)

- 'I can't do what I think would be-would be--' / 'Right?' / 'No, wise.' (29 - looking for the right word)

-'We thought-_-' began Gabriel / 'I am driving to Bath.' (precedence - 166)

Also: '[...] a face as big as a baking trendle-_' / 'But that's nothing to do with mistress!' (172) (similar cases with Liddy: 154)

- 'I love Fanny best now,' said Troy; 'But Bathsh--Miss Everdene inflamed me [...]' (slip of the tongue -178)

- 'Think if you will, and be d--' The sentence was completed by a smart cut of the whip

[...].' (interruption \& erasure - 202)

- ‘[...] why I-I will--' / 'Promise!' / --Consider, if I cannot promise soon.' (solicitation \& prevarication - 271)

\section{Aposiopesis:}

- 'People disturbing women at this time of night ought--' / Gabriel took the key [...]. ( frustration - 191)

- [...] 'he was fighting against water now-and for the futile love of the same woman. As for her-- But Oak was generous and true, and dismissed his reflections. (actorial - 197)

- 'And, Joseph-_' / 'Yes, ma'am.' (tragedy - 213)

- 'I am sorry you thought I-_' / 'I have always this dreary pleasure in thinking over those past times with you [...]' (unease, repression - 269)

- 'I wish Troy was in--. Well God forgive me for such a wish!' (blasphemy \& self-reproach 284)

- 'A woman's good name is such a perishable article that--' / Bathsheba laughed with a flushed cheek [...]. (teasing - 306)

All cases:

Fifty-seven occurrences: 10, 22, 23, 26, 28, 29 (two cases), 31, 42, 43 (two cases), 49, 51 (two cases), 56, 65, 72, 86, 101, 108, 125, 129, 134, 143, 149, 154, 166, 170, 172, 177, 178, 180, 181, 191, 197, 201, 202, 213, 215, 221, 234, 236, 251, 256, 269, 270, 271 (two cases), 272, 273, 279, 284, 286, 302 (two cases), 303, 306.

\section{B. Ellipsis: spaced dots / 'ellipse ajourée' $=\ldots$}

\section{Conventional (suspension dots)}

- 'Never had such a struggle in my life....' (suggestion \& emphasis - 198; also 154) 
- ‘[...] and I can’t fend off my miserable grief! ...' (self-pity - 199)

\section{Actorial and auctorial}

- 'I don't like your concerns going to ruin, as they must if you keep in this mind. ... I hate taking my own measure so plain [...].' (Oak's daring \& self-defence - 151)

- 'Unfeeling thing that you are. . . . But I'll see if you [...] dare do such a thing.' (154)

- 'Did she walk along our turnpike-road?' she said, in a suddenly restless and eager voice.

/ 'I believe she did. . . . Ma'am, shall I call Liddy?' (Joseph's unease \& panic - 214)

- 'O if I could only pay [...] and so get the sin off my soul that way! ... Well there's the debt [...].' (naivety \& dramatic irony - 273)

\section{Plot (v. story)}

- 'I do hope she has come to no harm through a man of that kind....' (double prolepsis 58)

- 'Would to God you would speak and tell your secret, Fanny! ... O, I hope, I hope it is not true that there are two of you! ... If I could only look in upon you for one little minute [... ].' (suspense \& climax - 227)

- 'I am not sure of that. .. She's a handsome woman, Pennyways, is she not?' (suspense 277)

\section{Aposiopesis}

'[...] and that his constancy could not be counted upon unless I at once became his.... And I was grieved and troubled--' She cleared her voice [...]. (two typographical forms of aposiopesis - 196)

\section{All cases:}

Thirty occurrences: 26 (two cases), 50, 51, 58, 118, 121, 129, 151, 154 (three cases), 158, 160, 161, 171, 196, 198, 199, 213 (two cases), 214, 222 (three cases), 227 (two cases), 229, 273, 277.

\section{C. 'm rule' / 'tiret cadratin' $=-3$}

\section{Conventional}

- '[...] and my businessman's-that is, yours-on morals.' (interpolated - 273)

- WHO DIED OCTOBER 9, 18- [...] (cancelled date \& "effet de réel" - 297)

- First came the words of Troy himself:- / ERECTED BY FRANCIS TROY [...]. (introductory 297). Simpler forms (not preceded by a colon): “[...] when Boldwood said suddenly and simply - / 'Mrs. Troy, you will marry again some day?'(269); many other similar cases: cf. p. $41,1.35 \& 41)$. 


\section{Mimetic}

- 'And your said lots of times you would marry me, and-and-I-I-I--' 'Don't cry, now!' (72)

- 'Because it-it isn't the correct one,' she femininely murmured. / 'O, fie-fie!' (135)

- 'That's unjust-but I won't repeat the remark.' (slight interruption - 137)

- 'O no-I don't think that.' / '-But the real truth of the matter is that there was not, as some fancy, any jilting on-her part.' (199)

- 'If she's-that,-what-am I?' (231)

\section{Plot}

- Figures stepped singly and in pairs through the doors-all walking awkwardly, and abashed [...]. (auctorial: descriptive \& evidential - 197)

- 'Good-bye till then. I am a brute-but good bye!' (actorial - 202)

- [...] her bitter voice being strangely low-quite that of another woman now. (auctorial \& actorial - 231)

- He uttered a long guttural sigh-there was a contraction-an extension-then his muscles relaxed, and he lay still. (climax, descriptive - 290)

\section{Aposiopesis}

- 'Maryann-O you perjured woman!' (indignation - 153)

- Instead of being a man trained to repression he was-what she had seen him. (auctorial \& actorial: revelation -161)

- 'Her meaning may be good; but there-she's young yet' (277)

\section{NOTES}

1. See the annexes.

2. "auctorial" refers to the judgment passed by the narrator on a character's attitude, in contradistinction to "authorial", indicating a commentary attributable to the author himself; "actorial" points to a purely descriptive information concerning a character's behaviour.

3. 'n rule or en rule' ('demi-cadratin' :-).

\section{ABSTRACTS}

The article examines the punctuation marks that signal narrative silences in Far from the Madding crowd. There are three series of typographical silence-markers: "2-m rules" or "2-m dashes", 
"ellipses", and "m rules" or "m dashes". These typographical signs, hardly noticed on first reading the text but necessarily interpreted by the reader, reproduce interruptions of speech which encapsulate some intense axiological exchange connected with the judgements on the characters' thoughts or actions that the text leads us to pass. The markers thus take on various functions (from mimesis to suspense and to the narrator's comments) which are essential to maintaining verisimilitude. The article ends on an assessment of such a persuasive strategy and of its effect on the reader, in a text which is undeniably influenced by the format of the serial publication it originally appeared under.

L'article s'intéresse aux signes de ponctuation marquant les silences narratifs dans Far from the Madding Crowd. Les marqueurs concernés sont de trois types : 1 . le double tiret cadratin ; 2 . les points de suspension et 3 . les tirets cadratins. Ce guidage typographique, à peine remarqué à première lecture mais nécessairement déchiffré par le lecteur, miment des interruptions de parole ou de discours qui sont le lieu d'un intense échange de nature axiologique ayant trait aux jugements que le texte nous fait émettre quant aux pensées ou actions des personnages en jeu. Les diverses fonctions ainsi assurées (de la dimension mimétique au suspens et aux commentaires $\mathrm{du}$ narrateur) sont essentielles pour assurer et maintenir le sentiment de vraisemblance et donc notre adhésion au texte. L'article se termine par une évaluation de cette démarche de persuasion narrative et de son action sur le lecteur, dans un texte qui reste influencé par la forme feuilleton sous laquelle il a d'abord été publié.

\section{INDEX}

Mots-clés: roman, ponctuation, typographie, stylistique, réception, lecteur, narration oeuvrecitee Far from the Madding Crowd

Keywords: novel, punctuation, typography, stylistics, reception, reader, narration

\section{AUTHOR}

\section{MICHEL MOREL}

Université de Nancy 2

Professeur émérite 